O livro de Stockton é moderno, e após definir claramente os conceitos, o que é uma raridade hoje em dia, chega, já no terceiro e quarto capítulos ao, "ponto de pedido" e "lote econômico". A dedução do lote econômico pelo autor parece um pouco anticlimática, pois após um exaustivo estudo das três alternativas de atendimento: a) entrega parcial, b) recepção (entrega) completa e c) preço variável, o autor chega à expressão matemática do custo total. Mas, depois não deduz ou deriva do custo total a fórmula do lote econômico, levado por uma vontade de evitar envolvimento do leitor com cálculo diferencial. Isso, porém, não faz mal, pois os outros livros citados tratam disso. O uso da solução tabular é muito interessante, apesar de que a constante do custo total anual de compra nem sempre precisa ser incluída, só quando há descontos de quantidade. Falta tornar isso bem claro. Os capítulos quinto e sexto são dedicados a sistemas de revisão periódica e suprimentos agregados, respectivamente. Mais uma vez acreditamos que se trata de algo inédito na literatura em português.

A flutuação de pontos de pedido é tratada ainda no quarto capítulo. O trabalho dos professores Zaccareli e Magee, respectivamente da Universidade de São Paulo e da Harvard Business School (na época), também existe em português, mas a reunião de todos os dados no mesmo lugar torna o livro essencialmente valioso. Infelizmente o sétimo capítulo é muito curto, uma vez que maior ênfase em sistemas integrados, que nele são tratados, teria dado um fecho de ouro ao livro.

Resumidamente, trata-se de um ótimo livro para o nível de graduação e pós-graduação em administração de empresas e em eriģenharia de produção, pressupondo um mínimo de cálculo diferencial (para achar máximo e mínimo) e de probabilidade, para achar estoques de reserva e cálculos de atendimento. Três objetivos poderão dar ao livro também utilidade industrial: difundir a teoria do atendimento, aumentar a sensibilidade sobre probabilidade de variação do consumo semanal ou mensal e, finalmente, tornar mais quantitativo o tratamento do problema de estoques industriais.
A tradução do livro está ótima. Há pequenos senões, que mudam - sentido de certas frases; por exemplo, na página $25,3^{a}$ linha do último parágrafo está: "são mais complexos e mais resolúveis", onde provavelmente deve ser menos. Na p. 17 está "complação" em lugar de contração de inventário. Exponencial smoothing foi traduzido como "suavização exponencial" (p. 29, nota 6), em lugar de "nivelamento exponencial", usado por outros autores. Sensitivity-analysis ficou "análise da sensitividade" - palavra que ainda não consta dos dicionários - o que é tão bom quanto "de sensibilidade" do resultado. O livro está sendo usado em seminário de nível pós-graduado, e está satisfazendo, logo, que mais será necessário? E um louvor à Editora Atlas por uma gama completa de livros sobre o assunto, que não concorrem entre si, mas se completam. E obrigado pela bibliografia adicional nacional.

atis

Kurt E. Weil

\section{Administração da Produção}

Por Raymond Richard Mayer. São Paulo, Editora Atlas, 2 v. 740 p. Bibliografia original, 1972. Tradução do original Production management, 1968, feita por Clovis Monteiro e Rubens Valdergoria (USP).

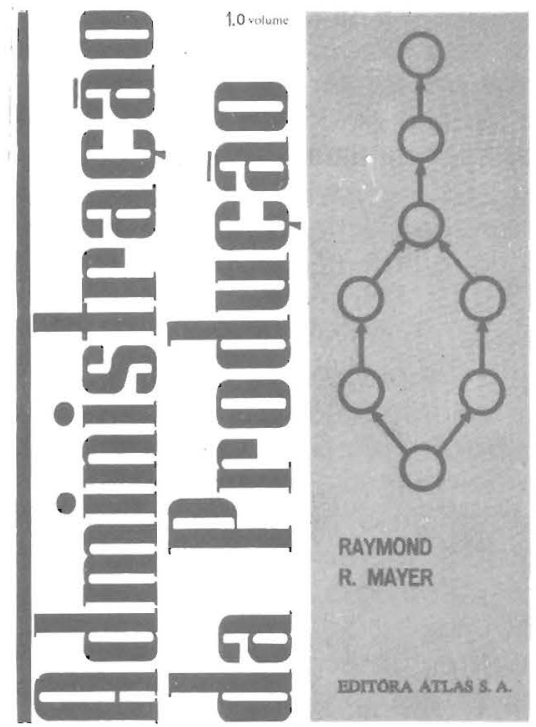

Com este livro finalmente temos uma escolha completa para o ensino da administração da produção - há livros de todas as escolas filosóficas escritos ou traduzidos para o português. Como professor e chefe de departamento, o autor desta resenha costuma deixar livre a escolha do livro mais indicado nos diversos cursos da Fundação Getulio Vargas e o mesmo deve acontecer nas faculdades de administração e engenharia pelo Brasil. É portanto necessário esclarecer a filosofia que deve nortear o ensino e o tipo de livro mais indicado para cada escolha de rumo. Da mesma maneira, na indústria, cada livro tem seu campo específico:

1. O ensino clássico: ponto por ponto se estuda em progressão sistemática o campo da administração da produção. Começa o estudo pela localização de empresas, passa-se pela construção da fábrica, layout, estudos de tempos e métodos, incentivos salariais, controles qualitativo e quantitativo da produção, planejamento da produção, estatística industrial (incluindo a probabilidade no capítulo do controle de qualidade), engenharia econômica, análise de investimentos, pesquisa operacional, incluindo PERT, teoria de fi- 
las, teoria de decisões e processamento de dados etc. Esse tipo de ensino é muito apropriado para cursos de graduação e para permitir uma base perfeita. Os livros que se encontram em português nessa categoria são Maynard (em fascículos em português, mas um só volume em inglês) e Machline, Sá Motta, Weil e Schoeps, da Fundação Getulio Vargas, em original português. A esses dois agora se adiciona o livro de Mayer, que apesar de não ter exatamente o índice mencionado, muito se aproxima dele.

$\mathrm{Na}$ indústria, esses livros servem de manuais, o que aliás foi levado em conta pela Fundação Getulio Vargas no título da obra citada.

2. A escola do ensino do "sistema produção": o estudo integrado $^{1}$ pressupõe conhecimentos anteriores - assim, o ensino do sistema de produção como integrado, inclusive com finanças e mercadologia, exige capacidade de resolução de casos, conhecimentos anteriores e muita leitura simultânea, para a qual parece faltar vontade, na opinião do autor da resenha, de $90 \%$ dos alunos pós-graduados, pois trabalham e não têm tempo.

O livro de Martin Starr Administração da produção: sistemas e sinteses - traduzido para o português e resenhado em inglès pelo mesmo autor desta resenha nesta revista, é o melhor exemplo do estudo integrado, com todas as suas vantagens e desvantagens. Vantagens na melhor adequação do homem à indústria e desvantagens porque há necessidade de dispersar conhecimentos na repetição de um mesmo assunto em diversos lugares, por exemplo, a regra de Laplace na 114 tomada de decisão e a programação da produção. Starr é o livro em português para cursos de pósgraduação.

Em inglês existem outros, como por exemplo, o de Gavett.

3. A escola do ensino de produção com a demonstração dos sistemas existentes: essa escola intermediária tem, traduzido para - português, o livro de Buffa $e$, em inglês, o livro de Moore. E o mais indicado para os últimos anos de escolas de administração e para escolas de engenharia nos cursos de engenharia de produção.
Assim posto, o livro de Mayer é recomendável para os seguidores da escola clássica de administração da produção e para o ensino em escolas de administração de empresas e de engenharia, onde, pela seriação, não é possivel dar o "sistema-produção" no ensino.

O livro de Mayer atinge seu ponto forte no capitulo de controle estatístico de qualidade, ao qual dedica 130 páginas $(17 \%)$; no entanto, é possivelmente menos completo para o gosto desse autor na "análise de investimento" (50 páginas), que inclui a análise de custos. ${ }^{2}$ No capítulo Controle de estoques sob risco (bom) deveria ser integrado mais o seguinte assunto: níveis de estoque e cronogramas de produção; isso permitiria uma melhor visualização do fenômeno da linha de produção. Mas, perguntase, como é possível criticar a extensão de um livro; o autor deve ter tido suas razões para limitar os assuntos tratados. Por conseguinte, o professor deve adotar um volume suplementar.

O livro tem casos de problemas de grande utilidade, no fim de cada capítulo, e com a "falta de tempo" (leia-se: cansaço, desânimo e preguiça) do professor universitário moderno - azafamado com consultorias, escolas diversas onde leciona, correçōes de provas, reuniōes e congressos científicos (se houver verbas) pode ser feita a sugestão de traduzir também o "livro do professor". Otima bibliografia. Livro bem traduzido, mas sem índice remissivo, que é um defeito num livro desse tamanho. "Ratio-delay" ficou "fração de atraso" (p. 629) ou "amostragem do trabalho" ( $p$. 623). Não são mais sinônimos; eram. O método por sinal é insuficientemente tratado em extensão e profundidade. Mas, não adianta, como já disse, pesquisar a intenção do autor.

Kurt E. Weil

1. Explicação: a diferença entre sistema como técnica contra a descriçâo clássica pode ser comparada ao estudo da ana. tomia descritiva que é necessária para entender $o$ funcionamento do sistema vida humana. Mas, sem anatomia descritiva, ninguém entende o sistema, por exemplo, de locomoção do homem, onde intervém desde o equilíbrio, os músculos, os ossos, os nervos, a vista, até o metabolismo, que dá a energia; portanto, seria o sistema biológico.

2 Do mesmo autor existe Análise financeira de alternativas de investimento. Traduzido também no mesma Editora Atlas. Esse livro explica porque somen te 50 páginas säo dedicadas ao assunto no livro de produção. 